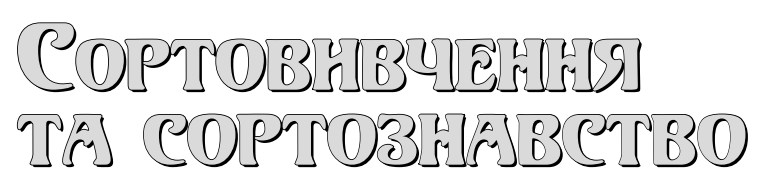

\title{
Peculiarities of the classification of economically valuable indicators of highbush blueberry varieties of Vaccinium corymbosum L.
}

\author{
S. I. Melnyk ${ }^{1}$, N. S. Orlenko ${ }^{1}$, N. V. Leshchuk ${ }^{1 *}$, V. M. Matus ${ }^{1}$, V. A. Pavliuk ${ }^{2}$, N. V. Pavliuk ${ }^{1}$ \\ ${ }^{1}$ Ukrainian Institute for Plant Variety Examination, 15 Henerala Rodymtseva St., Kyiv, 03041, Ukraine, *e-mail: nadiya1511@ukr.net \\ ${ }^{2}$ FOP "Pavliuk V. A.", 4-A Ozerna St., apt. 37, Novosilky, Kyiv-Sviatoshynskyi district, Kyiv region, 03027, Ukraine
}

Purpose. To substantiate the features of the classification of morphobiological and economically valuable indicators of highbush blueberry varieties of Vaccinium corymbosum L. Methods. The studies were carried out during $2012-2019$. Research methods: field (visual examination of the manifestation of morphological signs of vegetative and generative organs of blueberry plants), laboratory (determination of the content of vitamin C, total sugar, pectin, carotenes, anthocyanins, flavonoids, total acidity in berries), analytical, comparative, statistical (cluster analysis). Results. Over the years of research, varieties of highbush blueberries were characterized by a stable manifestation of homogeneous morphological traits and economically valuable performance indicators. In particular, the studied varieties are classified according to ripeness groups: very early: 'Fiolent'; early: 'Draper', 'Huron', 'Clockwork', 'Cargo', 'Laska'; medium: 'Blue Ribbon', 'Top shelf', 'ZF08-070', 'Mavka'; late: 'Liberti', 'Last Call' and very late: 'Aurora', 'Overtime'. It was determined that the quantitative morphological traits of highbush blueberry varieties that influenced the formation of plant productivity include such traits as growth vigor, leaf length, leaf width, inflorescences lengthwise, bunch density, fruit size. Economically valuable indicators of suitability of highbush blueberry varieties remained stable within the ripeness group. The highest yield (19.5 t/ha) was provided by the mid-season variety 'Mavka' of domestic selection. The yield of berries from the bush of this variety was also high and amounted to $7 \mathrm{~kg}$. The studied performance indicators were low in the variety 'Blue Ribbon' - $10.2 \mathrm{t} / \mathrm{ha}$ and $2.4 \mathrm{~kg}$, respectively. The minimum and maximum values of the manifestation of characteristics will serve to establish the limiting boundaries of its variation in the next modeling of economically valuable indicators of highbush blueberry varieties. Conclusions. Such morphobiological characteristics of highbush blueberry varieties, as plant growth vigor, leaf length, leaf width, inflorescences lengthwise, bunch density, fruit size are closely related to plant productivity, berry yield per bush, berry weight and yield. Therefore, they can be involved in the development and improvement of the model of suitability indicators of highbush blueberries for distribution in Ukraine.

Keywords: morphological features; suitability indicators; homogeneity of signs; pomological signs.

\section{Introduction}

Domestic gardeners face new challenges to meet the demand for valuable, environmen-

Serhii Melnyk

https://orcid.org/0000-0002-5514-5819

Nataliia Orlenko

https://orcid.org/0000-0003-0494-2065

Nadiya Leschuk

https://orcid.org/0000-0001-625-3702

Valentyna Matus

https://orcid.org/0000-0002-2267-4757

Viktor Pavliuk

https://orcid.org/0000-0001-8510-5116

Nataliia Pavliuk

https://orcid.org/0000-0003-2532-7301 tally friendly food products with a high content of vitamins, macro-, microelements and other vital substances [1,2]. Currently, it is not enough to obtain high stable yields of berries through the introduction of scientific achievements and advanced experience, but it is important to expand the range of offered products [3]. Therefore, an important issue is the distribution of crops traditionally not widespread in Ukraine, such as highbush blueberries.

A significant factor in increasing the production of fruit and berries products is also an increase in the level of its yield due to intensification, improvement of growing technology and the introduction of new highly productive varieties for various agroclimatic growing zones. In 
2000 , the average yield of a group of fruit and berry crops was only $3.84 \mathrm{t} / \mathrm{ha}$, in $2005-6.37$, in $2010-7.82,2018-12.84$ t/ha [4].

Among the factors of the formation of a high level productivity of fruit and berry crops, the ecological plasticity of plant varieties should be noted. The introduction of new varieties of berry crops enables to obtain a high yield and high quality of berries - with better taste, more attractive appearance, long keeping quality and better transportability [5].

According to the State Statistics Service of Ukraine, until 2017, there was a gradual annual decrease in the area of plantations of fruit and berry crops (Fig. 1). An increase in the area of laying gardens, almost 8.8 times, was noted in 2018 , which is a positive trend in the development of the fruit and vegetable industry [4].

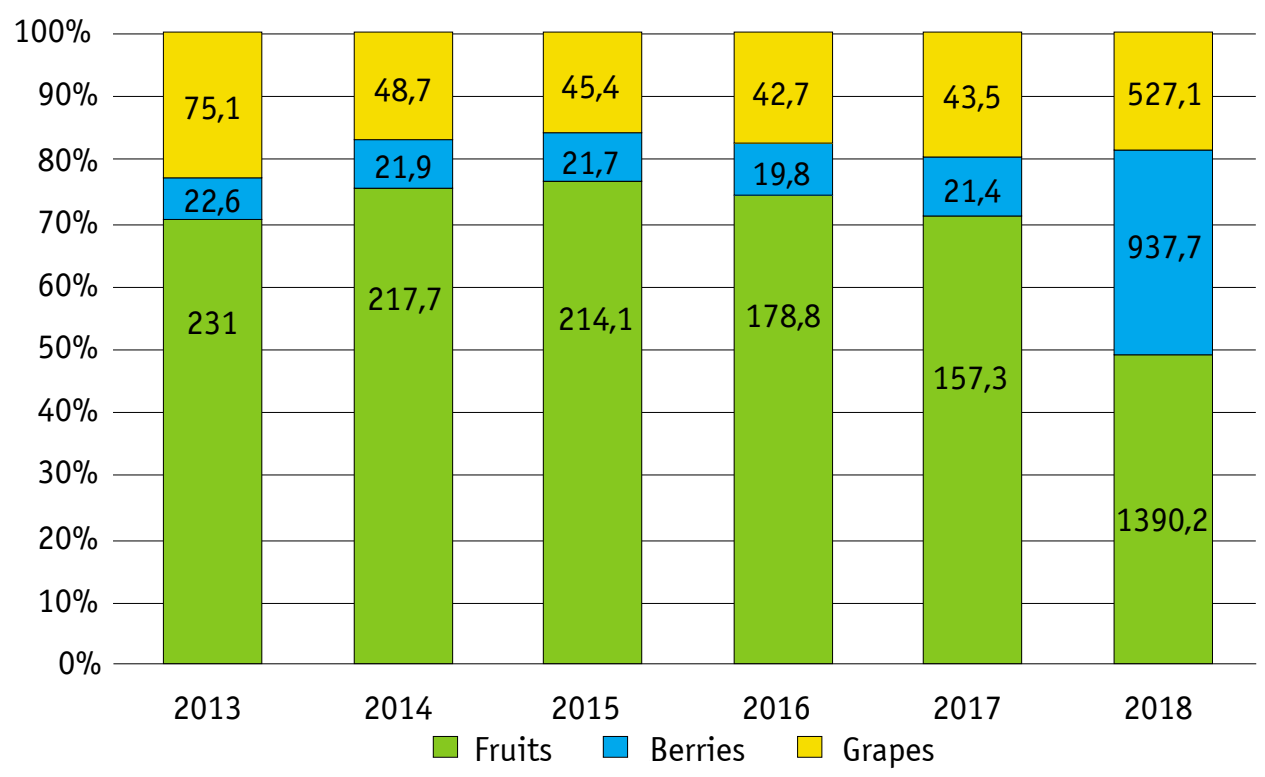

Fig. 1. Areas of plantations of fruit and berry crops and grapes in Ukraine, thousand hectares [4]

Based on approved programs, in particular the Sectoral Program for the Development of Horticulture in Ukraine for the period up to 2025, which provides for support measures that are likely to further increase the area. First of all, these are scientific research, training of personnel, promotion of the sale of fruit and berry products, subsidies, com- pensation for part of the costs of mineral fertilizers and plant protection products, price support, preferential lending to commodity producers, etc. [6].

The dynamics of filing applications for plant varieties of fruit crops by domestic applicants is heterogeneous and does not exceed the number of applications filed for varieties of foreign

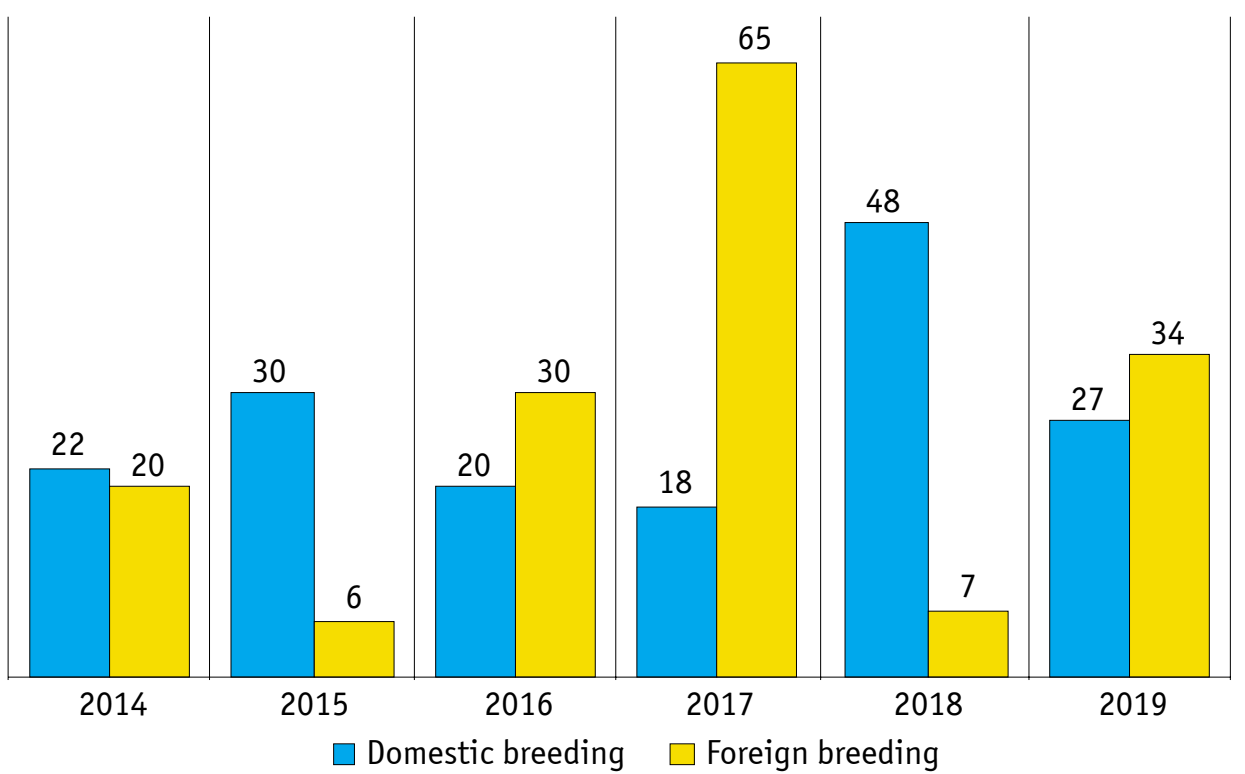

Fig. 2. Dynamics of filing applications for varieties of berry crops by origin 
breeding. An increase in the number of applications for varieties of Ukrainian breeding over foreign varieties can be traced in 2018, which is 6.4 times more than in previous years (Fig. 2).

The analyses of the varieties of the fruit and berry group that passed the state registration and form the basis of the technologies for the production of commercial products are shown in Figure 3.

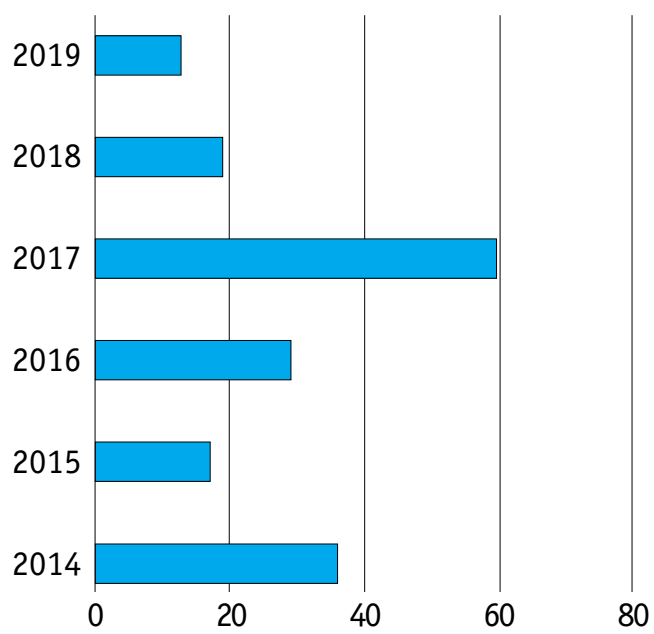

Fig. 3. Dynamics of registration of berry species varieties in 2014-2019, pcs.

In the domestic market of berry products of rare introduced species, highbush blueberries are in the lead today, and its areas are constantly increasing. State register of plant varieties suitable for distribution in Ukraine, today includes 14 varieties of highbush blueberry Vaccinium corymbosum L. [7].

Analysis of plant varieties catalogs of the member countries of the International Union for the Protection of New Varieties of Plants (UPOV) showed that highbush blueberry varieties (Vaccinium corymbosum L.) for 2018-2019 hit the market only in Canada (6 varieties in 2 years) and Poland (2 varieties in 2018).

Improvement of the elements of technology for growing blueberries made it possible to offer the production of basic technologies for industrial plantings and private sector in the open field using artificial substrates, materials for mulching and trellis [8-10]. The experience of recent years in Poland testifies to the high efficiency of its cultivation in protected soil, which enable to accelerate the flow of berry products by 10-20 days and extend its active use until October. The prospects for the distribution of blueberries in Ukraine largely depend on the varietal composition and agrotechnical measures for reproduction and cultivation. It has a wide ecological amplitude and plasticity of climatic indicators, withstands sharp tem- perature changes well and easily adapts to various environmental conditions [14, 15].

An important indicator of the successful introduction of North American highbush blueberry varieties is their ability to adapt to new conditions. The limiting factors for the distribution of highbush blueberry varieties are the duration of the growing season, the sum of effective temperatures during the growing season, as well as low temperatures in spring, autumn and winter, which cause freezing of the root system and aboveground part [16].

Currently, a number of indicators are used to determine the suitability of a variety for distribution in Ukraine, for example, growth vigor; ripeness group; yield, t/ha; yield, kg/bush; average weight of a berry, $\mathrm{g}$, content of vitamin $\mathrm{C}$ in the berries, $\mathrm{mg} / 100 \mathrm{~g}$ of total sugar, \%; pectin substances, $\mathrm{mg} / 100 \mathrm{~g}$ carotene, $\mathrm{mg} / 100 \mathrm{~g}$ anthocyanins, $\mathrm{mg} / 100 \mathrm{~g}$ flavonoids, $\mathrm{mg} / 100 \mathrm{~g}$ total acidity, \%; tasting score, point (1-9) transportability of berries, point (1-9) winter hardiness, point (1-9) degree of freezing, point (1-9) drought resistance, point (1-9) pathogen resistance, point (1-9) pest resistance, score (1-9).

Therefore, the study of morphobiological characteristics of varieties is one of the main conditions for studying the degree of adaptation of introduced species and confirming the stable manifestation of traits and obtaining a high level of productivity.

The aim of the research is to substantiate the features of the classification of morphobiological and economically valuable indicators of high-growing blueberry varieties Vaccinium corymbosum L.

\section{Materials and methods}

The studies were carried out during 20122019. In accordance with the Methodology for the examination of plant varieties of a group of fruit, berry, nut bearing trees and grapes for distinctness, uniformity and stability: Bilberry (blueberry) [17], Methods for the examination of plant varieties of a group of fruit, berry, nut-bearing trees, subtropical and grapes for suitability for distribution in Ukraine: berry crops [18] and Methods of state scientific and technical expertise of plant varieties. Methods for determining the quality indicators of crop production were also used [19]. The material for the research was the seedlings, bushes of highbush blueberry varieties at the collection field sites of the Ukrainian Institute for Plant Variety Examination and the results of descriptions of the morphological characteristics of the varieties included in the UIPVE databases (Table 1). 
Blueberry varieties, widespread in Ukraine as of 2020

\begin{tabular}{|c|c|c|c|c|c|}
\hline $\begin{array}{c}\text { Application } \\
\text { number }\end{array}$ & Variety name & $\begin{array}{l}\text { Application } \\
\text { date }\end{array}$ & $\begin{array}{l}\text { Applicant } \\
\text { code }\end{array}$ & Applicant name & $\begin{array}{l}\text { Year of } \\
\text { registration }\end{array}$ \\
\hline $\begin{array}{l}08489001 \\
08489002 \\
08489003\end{array}$ & $\begin{array}{l}\text { 'Aurora' } \\
\text { ‘Liberty' } \\
\text { ‘Draper' }\end{array}$ & 24.11.2008 & 1336 & Board Of Trustees Operating Michigan State University & 2012 \\
\hline 13519001 & 'Fiolent' & 12.07.2013 & 1085 & Dmytriiev Volodymyr Ihorovych & 2015 \\
\hline 13519002 & 'Huron' & 17.12.2013 & 1976 & Board Of Trustees Operating Michigan State University & 2017 \\
\hline $\begin{array}{l}17501001 \\
17501002 \\
17501003 \\
17501004 \\
17501005 \\
17501006 \\
17501007\end{array}$ & $\begin{array}{l}\text { ‘Blue Ribbon' } \\
\text { ‘Clockwork' } \\
\text { ‘Overtime' } \\
\text { 'ZF08-070' } \\
\text { ‘Cargo' } \\
\text { ‘Last Call' } \\
\text { ‘Top Shelf' }\end{array}$ & 11.09.2017 & 2315 & Fall Creek Farm and Nursery, Inc. & 2019 \\
\hline $\begin{array}{l}18519001 \\
18519002\end{array}$ & $\begin{array}{l}\text { ‘Laska' } \\
\text { 'Mavka' }\end{array}$ & 02.03.2018 & 2470 & Durbak Andrii Myronovych & 2019 \\
\hline
\end{tabular}

During highbush blueberry plants growth and development, phenological observations and biometric measurements were performed on each of 5 typical bushes. A single repetition was carried out in the collection nursery of the Sumy branch of UIPVE. The beginning of the growing season in most of the studied varieties was observed on March 25-30 at an average daily air temperature of $5-7{ }^{\circ} \mathrm{C}$ (Fig. 4).
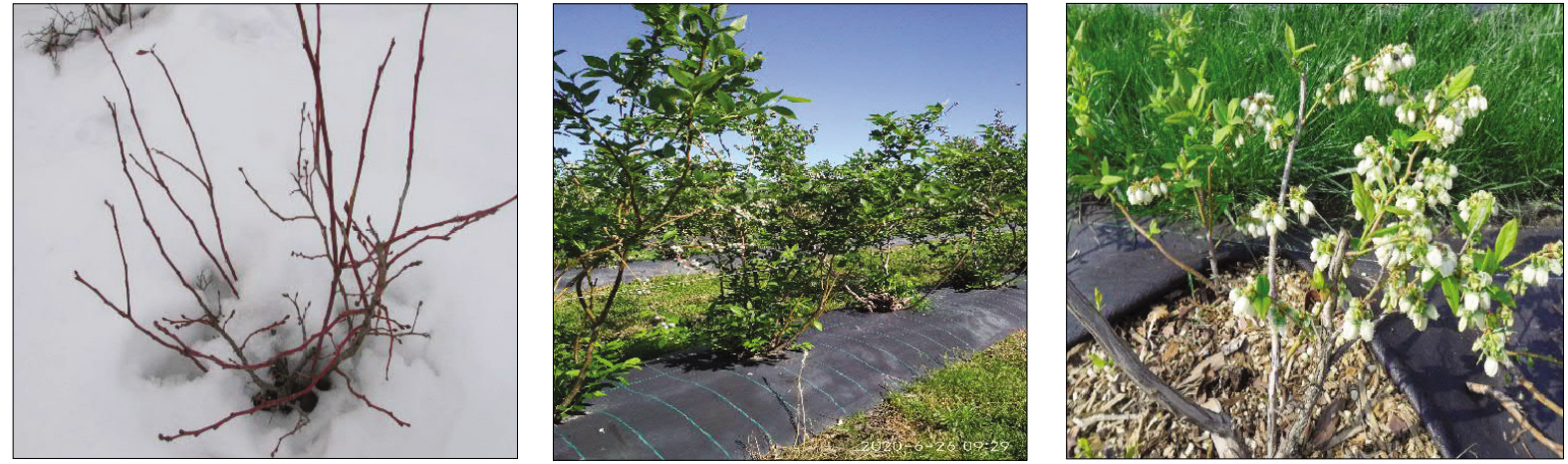

Fig. 4. Restoration and extension of the growing season of highbush blueberry bushes

In the first ten days of April, when the sum of effective temperatures reached $40-45{ }^{\circ} \mathrm{C}$, the beginning of bud cracking was observed in all varieties with a corresponding variation in the number of days. Depending on the ripeness group and environmental factors, studied highbush blueberry varieties differed in the rate of passage of the phenological phases of growth and development and the duration of interphase periods. The fruits ripened in 49-95 days.

The ripening period fluctuated within a month, so the crop was harvested three times.

Biometric measurements were carried out for morphological pomological features: leaf lengthwise, leaf width, inflorescences lengthwise, bunch density, fruit size.

Statistical analysis of the research results was carried out using dispersion and cluster methods with $\mathrm{R}$ programming language and the Statistica-10 application [20].

\section{Results and Discussion}

Over the years of research, highbush blueberry varieties provided a stable manifestation of homogeneous morphological characteristics and economically valuable indicators of plant productivity. We studied the quantitative mor-

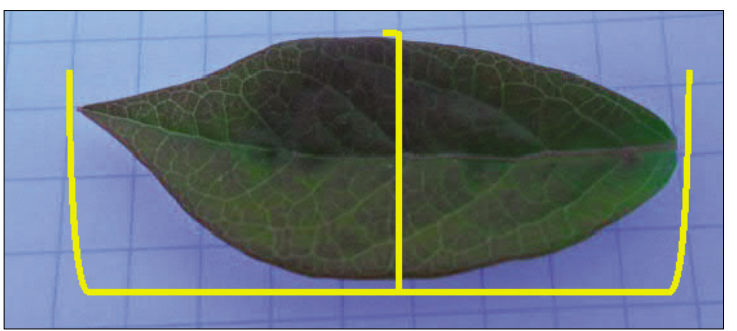

Fig. 5. Leaf: length and width

The length of the leaf in highbush blueberries is conventionally divided into a long one ('Blue Ribbon', 'Overtime', 'Last Call'); medium ('Fiolent', 'Draper', 'Huron', 'Clockwork', 'Cargo', 'Laska', 'Top Shelf', 'Mavka', 'Liberty', 'Aurora'); short ('ZF08070'). 
phological characteristics of highbush blueberry varieties, which influenced the formation of plant productivity, the yield of berries from one bush and the yield in general. The quantitative ones included: plant growth vigor, leaf length, leaf width, inflorescences length, bunch density, fruit size.

Varieties with narrow, medium and wide leaves are distinguished by the width of a leaf. Wide leaves are typical for 'Cargo' and 'Top Shelf' varieties. Only one variety, 'Mavka', has narrow leaves. The area of the leaf apparatus of highbush blueberry varieties is sufficient to

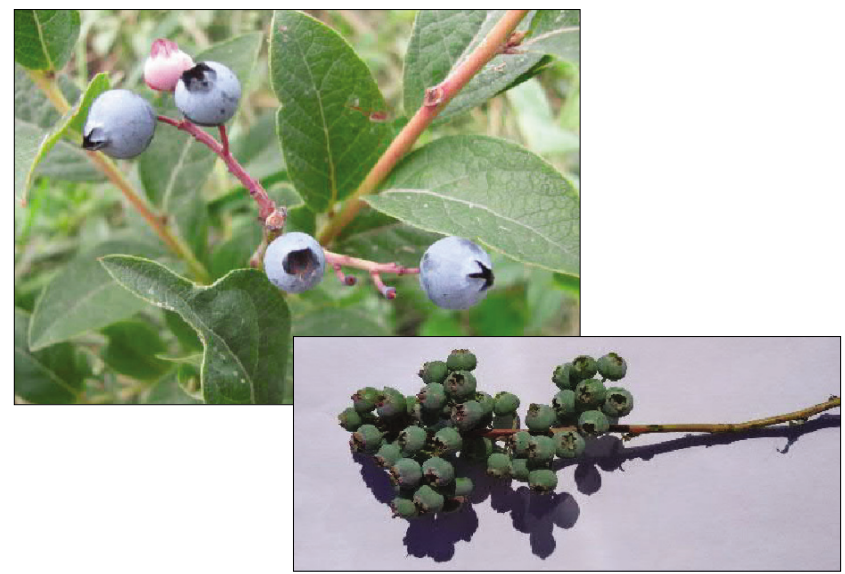

Fig. 6. Highbush blueberry inflorescences ensure photosynthetic processes of productivity formation.

Inflorescences of highbush blueberries are a bunch, which length and density affect the formation of plant productivity. There are single inflorescences, short and loose, or, conversely, short, but rather dense ('Draper'). Most varieties have long inflorescences ('Fiolent', 'Cargo', 'Last Call', 'Top Shelf', 'Mavka').

The fruit is a berry of various shapes, colors, mass, size and consistency. It is the size of a fruit that is one of the links in the formation of the productivity of highbush blueberry plants.

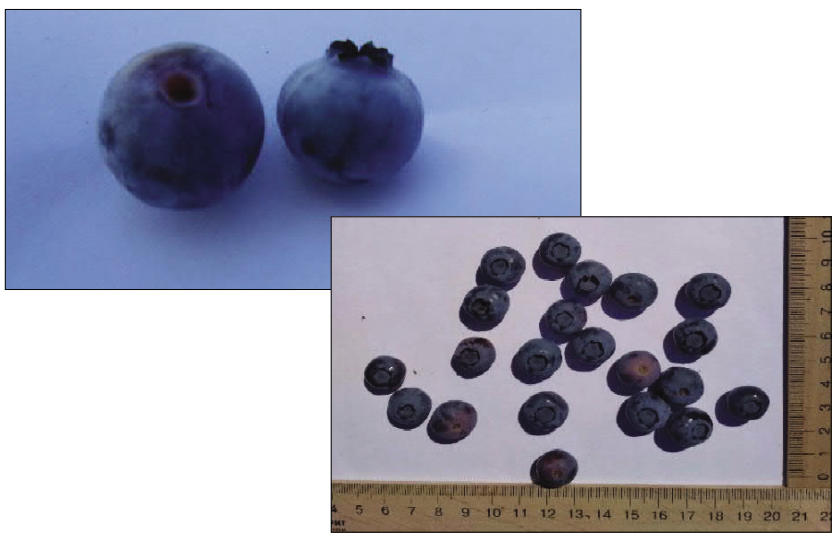

Fig. 7. Fruit (berry) of highbush blueberry

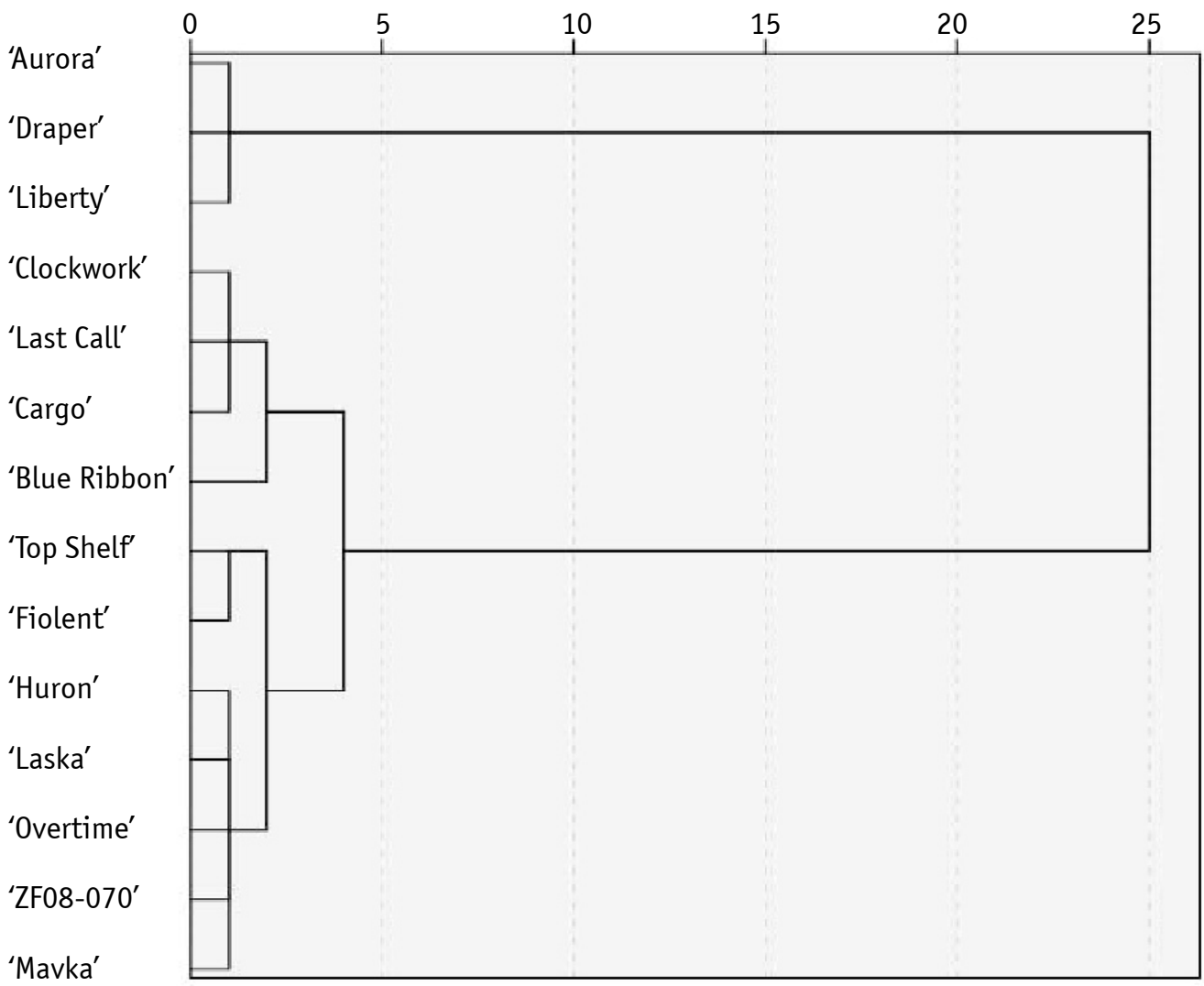

Fig. 8. Clustering of highbush blueberry varieties by morphological characteristics, affecting plant productivity using the Ward-Method 


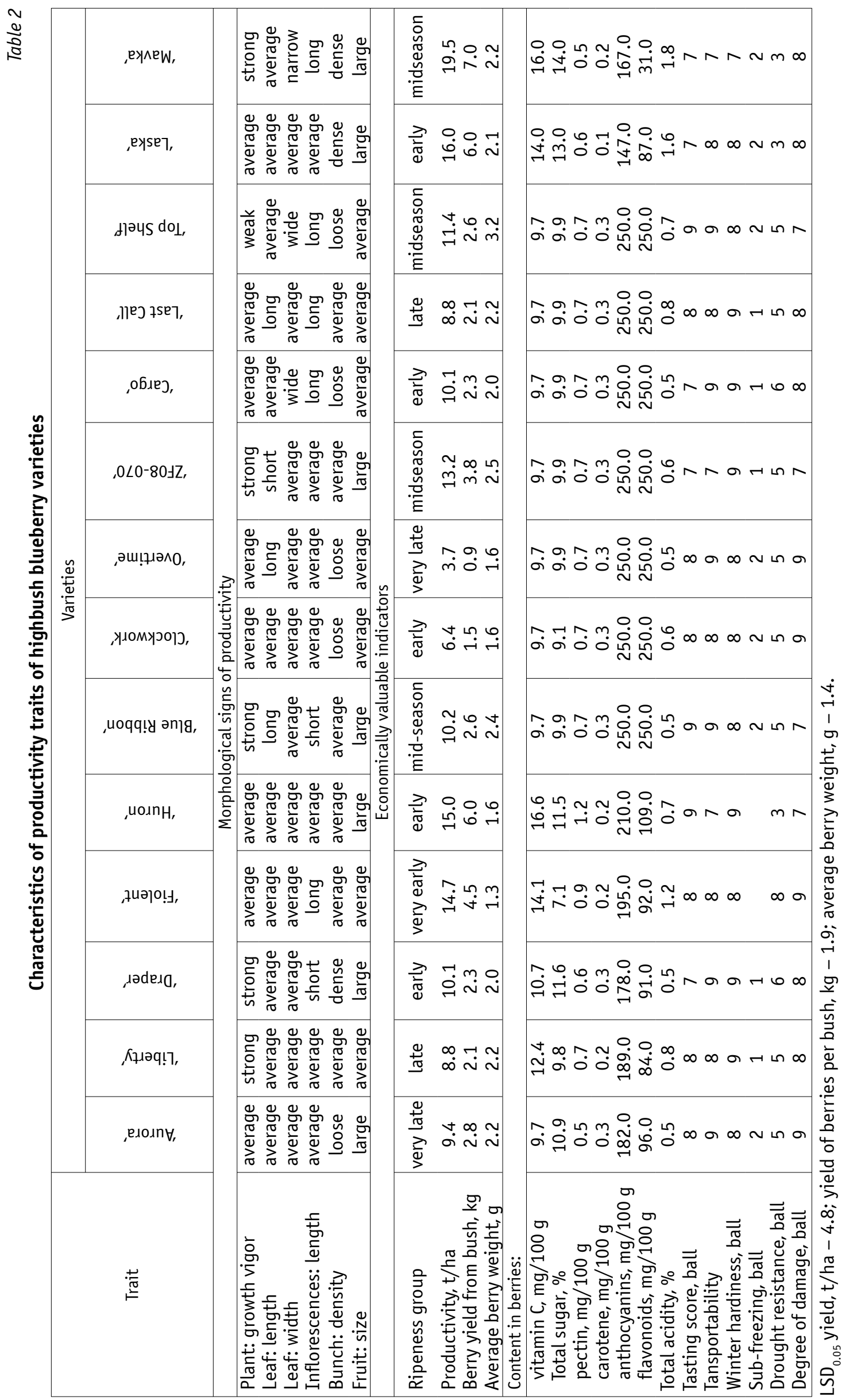


The highbush blueberry varieties 'Draper', 'Huron', 'ZF08-070', 'Blue Ribbon', 'Liberty', 'Laska', 'Mavka', 'Aurora' formed large fruits and had an average density of the brush and, in general, provided high productivity of plants, high yield of the mass of berries from the bush and productivity of highbush blueberries in general. The productivity of highbush blueberry plants, in addition to the above quantitative morphological characters, was influenced by such characteristics of berries as hardness, sugar content and acidity (Fig. 8). It is important to evaluate not only the yield potential, quality and pomological characteristics of fruits, but also plants regenerative abilities, as a manifestation of adaptability and components of economic value.

According to the research results, highbush blueberry varieties are assigned to ripeness groups: very early - 'Fiolent'; early - 'Draper', 'Huron', 'Clockwork', 'Cargo', 'Weasel'; medium - 'Blue Ribbon', 'Top Shelf', 'ZF080 70', 'Mavka'; late - 'Liberty', 'Last Call' and very late - 'Aurora', 'Overtime'.

Currently, to determine the suitability of a variety for distribution in Ukraine, such indicators as growth vigor; ripeness group; yield, $\mathrm{t} / \mathrm{ha}$; yield, $\mathrm{kg} / \mathrm{bush}$; the average weight of the berry, $\mathrm{g}$, the content of vitamin $\mathrm{C}$ in the berries, $\mathrm{mg} / 100 \mathrm{~g}$ of total sugar, \%; pectin substances, $\mathrm{mg} / 100 \mathrm{~g}$ carotene, $\mathrm{mg} / 100 \mathrm{~g}$ anthocyanins, $\mathrm{mg} / 100 \mathrm{~g}$ flavonoids, $\mathrm{mg} / 100 \mathrm{~g}$ total acidity, \%; tasting score, ball (1-9) transportability of berries, ball (1-9) winter hardiness, ball (1-9) sub-freezing, ball (1-9) drought resistance, ball (1-9) pathogen resistance, ball (1-9) pest resistance, ball (1-9) are used.

The minimum and maximum values of signs manifestation are indicative for establishing the limiting boundaries of variation when modeling economically valuable indicators of highbush blueberry varieties, which will help to develop and improve the model of indicators of highbush blueberries suitability for distribution in Ukraine.

The highest yield (19.5 t/ha) was provided by the mid-ripening large-fruited variety 'Mavka' of domestic breeding, it also had a high yield of berries per bush $-7 \mathrm{~kg}$. The lowest studied performance indicators in the mid-ripening group were in the variety 'Blue Ribbon' - 10 . $2 \mathrm{t} / \mathrm{ha}$ and $2.4 \mathrm{~kg}$, respectively (Table 2 ).

\section{Conclusions}

Blueberry varieties are classified into the following ripeness groups: very early - 'Fiolent'; early - 'Draper', 'Huron', 'Clockwork',
'Cargo', 'Laska'; medium - 'Blue Ribbon', 'Top Shelf', 'ZF08-070', 'Mavka'; late - 'Liberty', 'Last Call' and very late - 'Aurora', 'Overtime'. Morphobiological characteristics of highbush blueberry varieties, for example, plant growth vigor; leaf length, leaf width, inflorescences length, bunch density, fruit size correlates with plant productivity, berry yield per bush, berry weight and yield.

The highest yield (19.5 t/ha) was ensured by the mid-ripening large-fruited variety 'Mavka' of domestic breeding, it also had a high yield of berries per bush $-7 \mathrm{~kg}$.

These indicators of highbush blueberry varieties suitability for distribution in Ukraine were studied: growth vigor; ripeness group; yield, $\mathrm{t} / \mathrm{ha}$; yield, $\mathrm{kg}$ /bush; the average weight of the berry, $\mathrm{g}$, the content of vitamin $\mathrm{C}$ in the berries, $\mathrm{mg} / 100 \mathrm{~g}$ of total sugar, $\%$; pectin substances, $\mathrm{mg} / 100 \mathrm{~g}$ carotene, $\mathrm{mg} / 100 \mathrm{~g}$ anthocyanins, $\mathrm{mg} / 100 \mathrm{~g}$ flavonoids, $\mathrm{mg} / 100 \mathrm{~g}$ total acidity, \%; tasting score, ball (1-9) transportability of berries, ball (1-9) winter hardiness, ball (1-9) sub-freezing, point (1-9) drought resistance, ball (1-9) pathogen resistance, ball (1-9) pest resistance, ball (1-9).

\section{Reference}

1. Zakharchuk, 0. V. (2011). Features of formation of national varietal resources. Ekonomika APK [The Economy of Agro-Industrial Complex], 12, 117-122. [in Ukrainian]

2. Zakharchuk, 0. V., \& Kropyvko, V. S. (2012). Formation of national varietal resources - a way to ensure food security of the country. Zbirnyk naukovykh prats Tavriiskoho derzhavnoho ahrotekhnolohichnoho universytetu. Ekonomichni nauky [Scientific papers of Tavria state agrotechnological university. Economic sciences], 5(2), 152-163. [in Ukrainian]

3. Hrynyk, I. V., Bublyk, M. 0., \& Barabash, L. 0. (2014). Current problems of horticulture development in Ukraine. Sadivnictvo [Horticulture], 68, 5-15. [in Ukrainian]

4. Derzhavna sluzhba statystyky Ukrainy. (2018). Roslynnytstvo Ukrainy. Statystychnyi zbirnyk [Crop production of Ukraine: Statistical collection] (pp. 77, 81). Kyiv: N.p. Retrieved from http://www.ukrstat.gov.ua/druk/publicat/kat_u/2019/zb/04/ zb_rosl_2018.pdf [in Ukrainian]

5. Shevchuk, M. Y., \& Bortnik, T. P. (2017). Lokhyna vysoka [Vaccinium corymbosum]. Lutsk: PP Ivaniuk. [in Ukrainian]

6. Haluzeva prohrama rozvytku sadivnytstva Ukrainy na period do 2025 roku [Sectoral program for the development of horticulture in Ukraine for the period up to 2025]. Retrieved from https://ips.ligazakon.net/document/FIN40145 [in Ukrainian]

7. Derzhavnyi reiestr sortiv roslyn, prydatnykh dlia poshyrennia $v$ Ukraini na 2020 rik [State Register of Plant Varieties Suitable for Distribution in Ukraine for 2020]. Retrieved from https:// agro.me.gov.ua/storage/app/uploads/public/5f6/4a7/cb5/ 5f64a7cb57601923477589.pdf [in Ukrainian]

8. Andrusiv, B. (2006). Vyroshchuimo chornytsiu [Let's grow blueberries]. Lviv: N.p. [in Ukrainian]

9. Balabak, A. F., Pyzhianova, A. A., \& Dmytriiev, V. I. (2017). Chornytsia vysokorosla (Vaccinium corymbosum L.). Biolohichni osoblyvosti, introduktsiia, sorty, tekhnolohiia rozmnozhennia $i$ vyrobnytstva [Blueberries are tall (Vaccinium corymbosum L.). Biological features, introduction, varieties, technology of reproduction and production]. Kyiv: N.p. [in Ukrainian] 
10. Pyatnitsa, F. S. (2006). Sortovye osobennosti razvitiya i plodonosheniya golubiki vysokorosloy (Vaccinium corymbosum L.) $v$ usloviyakh Belorusskogo Poles'ya [Varietal features of development and fruiting of tall blueberry (Vaccinium corymbosum L.) in the conditions of the Belarusian Polesie] (Cand. Agric. Sci. Diss.). Minsk, V. F. Kuprevich Institute of Experimental Botany, Belarus. [in Russian]

11. Ochmian, I., Grajkowski, J., \& Ostrowska, K. (2006). Growth and yield of American blueberry (Vaccinium corymbosum L.) of 'Patriot' cultivar grown on here types of organic bed. EJPAU, 9(3), 156-167. Retrieved from http://www.ejpau.media.pl/ volume9/issue3/art-16.html

12. Pliszka, K. (2002). Promising highbush blueberry and lingonberry slections in Poland. Acta Hortic., 574, 157-158. doi: 10.17660/ActaHortic.2002.574.22

13. Smolarz, K. (2009). Uprawa borówki i żurawiny. Warszawa: Hortpress Sp.z.o.o. [in Polish]

14. Balabak, A. F., \& Pyzhianova, A. A. (2013). Introduction and prospects of growing tall blueberry (Vaccinium corymbosum L.) varieties in the Right-Bank Forest-Steppe of Ukraine. Zbirnik naukovih prac Umans'kogo nacional'nogo universitetu sadivnictva [Collection of Scientific Papers of Uman National University of Horticulture], 82(1), 94-100. [in Ukrainian]

15. Pyzhianova, A. A., \& Balabak, A. F. (2013). Introduction and perspectives of growing varieties of Highbush blueberry in the RightBank Forest-Steppe. Agrobiologiâ [Agrobiology], 10, 47-50. [in Ukrainian]

16. MacKenzie, K. E. (1997). Pollination requirements of three highbush blueberry (Vaccinium corymbosum L.) cultivars. J. Am. Soc. Hortic. Sci., 122(6), 891-896. doi: 10.21273/ JASHS.122.6.891

17. Tkachyk, S. 0. (Ed.). (2014). Metodyka provedennia ekspertyzy sortiv roslyn na vidminnist, odnoridnist ta stabilnist (VOS-test). Plodovi, yahidni, horikhoplidni ta vynohrad [Methods of examination of plant varieties for difference, homogeneity and stability (BOC test). Fruit, berry, nuts and grapes]. Kyiv: N.p. [in Ukrainian]

18. Tkachyk, S. 0. (Ed.). (2015). Metodyka provedennia ekspertyzy sortiv roslyn hrupy plodovykh, yahidnykh, horikhoplidnykh, subtropichnykh ta vynohradu na prydatnist do poshyrennia $\mathrm{v} U$ kraini (PSP) [Methods of examination of plant varieties of fruit, berry, nut, subtropical and grape for suitability for distribution in Ukraine (PSP)]. Vinnytsia: Nilan-LTD. [in Ukrainian]

19. Tkachyk, S. 0. (Ed.). (2015). Metodyka derzhavnoi naukovotekhnichnoi ekspertyzy sortiv roslyn. Metody vyznachennia pokaznykiv yakosti produktsii roslynnytstva [Methods of state scientific and technical examination of plant varieties. Methods for determining the quality of crop products]. Vinnytsia: Nilan-LTD. [in Ukrainian]

20. Prysiazhniuk, 0. I., Karazhbei, H. M., Leshchuk, N. V., Tsyba, S. V., Mazhuha, K. M., Brovkin, V. V., Symonenko, V. A., \& Maslechkin, V. V. (2016). Statystychnyi analiz ahronomichnykh doslidnykh danykh $v$ paketi Statistica 10.0 [Statistical analysis of agronomic research data package Statistica 10]. Kyiv: Nilan-Ltd. [in Ukrainian]

\section{Використана література}

1. Захарчук 0. В. Особливості формування національних сортових ресурсів. Економіка АПК. 2011. № 12. С. 117-122.

2. Захарчук 0. В., Кропивко В. С. Формування національних сортових ресурсів - шлях до забезпечення продовольчої безпеки країни. 36. наук. праць Таврійського держ. агротехнол. ун-ту. Економічні науки. 2012. Т. 5, № 2. С. 152-163.
3. Гриник I. В., Бублик М. О., Барабаш Л. 0. Актуальні проблеми розвитку галузі садівництва в Україні. Садівництво. 2014. Вип. 68. С. 5-15.

4. Рослинництво України : Статистичний збірник / Державна служба статистики України. Київ, 2018 C. 77, 81. URL: http:// www.ukrstat.gov.ua/druk/publicat/kat_u/2019/zb/04/zb_ rosl_2018.pdf

5. Шевчук М. Й., Бортнік Т. П. Лохина висока. Луцьк : ПП Іванюк, 2017. $230 \mathrm{C}$.

6. Галузева програма розвитку садівництва України на період до 2025 року. URL: https://ips.ligazakon.net/document/ FIN40145

7. Державний реєстр сортів рослин, придатних для поширення в Україні на 2020 рік. URL: https://agro.me.gov.ua/storage/app/ uploads/public/5f6/4a7/cb5/5f64a7cb57601923477589.pdf

8. Андрусів Б. Вирощуймо чорницю. Львів, 2006. 110 с.

9. Балабак А. Ф., Пиж'янова А. А., Дмитрієв В. І. Чорниця високоросла (Vaccinium corymbosum L.). Біологічні особливості, інтродукція, сорти, технологія розмноження і виробництва. Київ, 2017. 288 с.

10. Пятница Ф. С. Сортовые особенности развития и плодоношения голубики высокорослой (Vaccinium corymbosum L.) в условиях Белорусского Полесья : автореф. дис. ... канд. біол. наук : спец. 03.00.05 «Ботаника» / Ин-т экспериментальной ботаники им. В. Ф. Купревича. Минск, 2006. 19 с.

11. Ochmian I., Grajkowski J., Ostrowska K. Growth and yield of American blueberry (Vaccinium corymbosum L.) of 'Patriot' cultivar grown on here types of organic bed. EJPAU. 2006. Vol. 9, Iss. 3. URL: http://www.ejpau.media.pl/volume9/ issue3/art-16.html

12. Pliszka K. Promising highbush blueberry and lingonberry slections in Poland. Acta Hortic. 2002. Vol. 574. P. 157-158. doi: 10.17660/ActaHortic.2002.574.22

13. Smolarz K. Uprawa borówki i żurawiny. Warszawa : Hortpress Sp.z.o.o., 2009. 252 p.

14. Балабак А. Ф., Пиж'янова А. А. Інтродукція та перспективи вирощування сортів голубики високорослої (Vaccinium corymbosum L.) у Правобережному Лісостепу України. 36. наук. пр. УНУС. 2013. Вип. 82, Ч. 1. С. 94-100.

15. Пиж'янова А. А., Балабак А. Ф. Біологічні особливості росту і розвитку маточних рослин сортів голубики високорослої (Vaccinium corymbosum L.) в умовах Правобережного Лісостепу України. Агробіологія. 2013. Вип. 10. С. 47-50.

16. MacKenzie K. E. Pollination requirements of three highbush blueberry (Vaccinium corymbosum L.) cultivars. J. Am. Soc. Hortic. Sci. 1997. Vol. 122, Iss. 6. P. 891-896. doi: 10.21273/ JASHS.122.6.891

17. Методика проведення експертизи сортів рослин на відмінність, однорідність та стабільність (ВОС-тест). Плодові, ягідні, горіхоплідні та виноград / за ред. С. О. Ткачик. Київ, 2014. С. 777-788.

18. Методика проведення експертизи сортів рослин групи плодових, ягідних, горіхоплідних, субтропічних та винограду на придатність до поширення в Україні (ПСП) / за ред. С. 0 . Ткачик. 2-ге вид., виправ. і доп. Вінниця : Нілан-ЛТД, 2015. С. 21-24.

19. Методика державної науково-технічної експертизи сортів рослин. Методи визначення показників якості продукції рослинництва / за ред. С. О. Ткачик. 4-те вид., виправ. і доп. Вінниця : Нілан-ЛтД, 2015. С. 113-116.

20. Присяжнюк 0. I., Каражбей Г. М., Лещук Н. В. та ін. Статистичний аналіз агрономічних дослідних даних в пакеті Statistica 10.0. Київ : Нілан-ЛТД, 2016. 54 с. 
УДК 634.737: 631.963.3

Мельник С. I. ${ }^{1}$, Орленко Н. С. ${ }^{1}$, Лещук Н. В. ${ }^{{ }^{*}}$, Матус В. М. ${ }^{1}$, Павлюк В. А. ${ }^{2}$, Павлюк Н. В. ${ }^{1}$ Особливості класифікації господарсько-цінних показників сортів лохини високорослої Vaccinium corymbosum L. Plant Varieties Studying and Protection. T. 16, № 3. C. 239-247. https://doi.org/10.21498/2518-1017.16.3.2020.214920

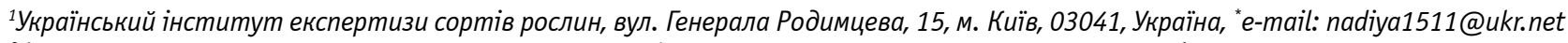
${ }^{2}$ ФОП «Павлюк В. А.», вул. Озерна, 4-А, кв. 37, с. Новосілки, Києво-Святошинський р-н, Київська обл., озо27, Україна

Мета. Обґрунтувати особливості класифікації морфобіологічних та господарсько-цінних показників сортів лохини високорослої Vaccinium corymbosum L. Методи. Дослідження проводили впродовж 2012-2019 рр. Методи дослідження: польовий (візуальне обстеження прояву морфологічних ознак вегетативних і генеративних органів рослин лохини), лабораторний (визначення вмісту в ягодах вітаміну C, загального цукру, пектину, каротинів, антоціанів, флавоноїдів, загальної кислотності), аналітичний, порівняльний, статистичний (кластерний аналіз). Результати. Сорти лохини високорослої за роки досліджень характеризувались стабільним проявом однорідних морфологічних ознак та господарсько-цінних показників продуктивності. Зокрема, досліджувані сорти класифіковані за групами стиглості: дуже рання: 'Фіолент'; рання: 'Драпер', ‘Гурон', ‘Клокворк', 'Карго', 'Ласка'; середня: 'Блу Ріббон', 'Топ шелф', 'ЗФ08070', 'Мавка'; пізня: 'Ліберті', 'Ласт Колл' та дуже пізня: 'Аврора', 'Овертайм'. Установлено, що до кількісних морфологічних ознак сортів лохини високорослої, які впливали на формування продуктивності рослин, належать такі ознаки, як сила росту, листок за довжиною, листок за шириною, суцвіття за довжиною, гроно за щільністю, плід за розміром. Господарсько-цінні показники придатності сортів лохини високорослої залишалися стабільними в межах групи стиглості. Найвищу врожайність (19,5 т/га) забезпечив середньостиглий сорт 'Мавка' вітчизняної селекції. Вихід ягід з куща в цього сорту був теж найвищим і становив 7 кг. Найнижчими досліджувані показники продуктивності були в сорту 'Блу Ріббон' - 10,2 т/га і 2,4 кг відповідно. Мінімальне та максимальне значення прояву характеристик слугуватиме для встановлення граничних меж його варіювання під час наступного моделювання господарсько-цінних показників сортів лохини високорослої. Висновки. Такі морфобіологічні характеристики сортів лохини високорослої, як сила росту рослин, листок за довжиною, листок за шириною, суцвіття за довжиною, гроно за щільністю, плід за розміром тісно пов'язані 3 продуктивністю рослин, виходом ягід 3 куща, масою ягід i врожайністю. А тому їх можна залучати до розроблення та вдосконалення моделі показників придатності лохини високорослої до поширення на території України.

Ключові слова: морфологічні ознаки; показники придатності; однорідність; помологічні характеристики.

Надійшла 10.08.2020

Погоджено до друку 22.09.2020 